\title{
Why I campaign for children like my son Alfie Dingley to be able to get medical cannabis
}

The high profile case of Alfie Dingley's intractable epilepsy was key to last year's law change. His mother, Hannah Deacon, explains why she now campaigns for the many families still fighting for access

Hannah Deacon mother of patient Alfie Dingley

Kenilworth, Warwickshire

My son Alfie, born in 2011, was perfect until he was 4 months old, when he became constantly sick. At 8 months he had his first tonic clonic seizure. He continued to have seizures in hospital for nearly four months. Intravenous steroids eventually stopped this cluster of seizures.

He lost every skill he'd developed, and he was diagnosed as having autoimmune epilepsy. Alfie had clusters of seizures every eight months until he was 4 years old. Then the clusters occurred every three weeks, and by the time he was 5 they came every week. Each time he needed up to five doses of intravenous steroids.

Then, Alfie was diagnosed with a rare epilepsy syndrome caused by a mutation in the gene that codes for the protein protocadherin 19. We were told that he might get better with age, but as far as we could see his health was getting worse. Only nine known boys worldwide have PCDH19 epilepsy, so prognosis was impossible.

\section{Treatments that worked}

I researched treatments for epilepsy. Medical cannabis kept coming up. In 1841 the Irish physician William Brooke O'Shaughnessy documented using cannabis for epilepsy. I learnt about the human endocannabinoid system and how cannabis medicines may work.

Alfie's doctors told us that regular steroids would eventually kill him. Cannabis medicines seemed his only chance to live. We started to campaign for Alfie to have a prescription for cannabis medicines in the UK, where they were illegal. Once we'd raised enough money, in September 2017, we moved to the Netherlands.

There we legally gave Alfie oil prepared from Bedrolite (produced by the Dutch company Bedrocan), a standardised strain of cannabis plant. The full extract cannabidiol (CBD) oil from this strain also contains other cannabinoids. Over three months Alfie's seizures became less frequent. We added tetrahydrocannabinol (THC) oil (Bedrocan's Bedica) under our paediatric neurologist's guidance, and Alfie went without seizures for 40 days. When he did have clusters they were less intense and controlled much more easily. His cognitive development greatly improved.

Living abroad, where we knew no one, was tough. After five months we ran out of money. We had to come home.

In the UK we had to fight for a prescription containing both CBD and THC. We continued to campaign. We wanted to work with the Home Office but encountered many obstacles. Finally, Mike Barnes, honorary professor of neurological rehabilitation at Newcastle University, successfully applied for the first UK licence for medical cannabis products for Alfie. Alfie received the first NHS prescription, for the products he'd been prescribed in the Netherlands, on 7 November 2018, after UK law changed on 1 November. ${ }^{1}$

Cannabis medicines are not cure-alls. Alfie still has occasional clusters, but they stop within hours rather than after days on end in hospital.

Many other children in similar situations have not been able to get these medicines despite now being legal. ${ }^{2}$ Reasons given have included lack of evidence, money, and support from NHS managers. I work with the campaign group End Our Pain, currently supporting 16 such families. It is heart breaking that seemingly no NHS doctor is willing or able to prescribe medicines that could help these children who have been very sick, some for many years, after having tried many other drugs.

\section{Guidance is just that}

England's health secretary, Matt Hancock, told the House of Commons on 8 April that the British Paediatric Neurology Association's guidance against prescribing full extract medical 
cannabis was just that—guidance—and that 95000 doctors in the UK could prescribe. ${ }^{3}$ So why are families still not getting prescriptions? Why was the law changed if access was not to be forthcoming?

I know of a child taking Bedrolite and Bedica in the UK, funded by the parents. Their doctor is overjoyed at the results yet says he cannot prescribe because of the BPNA's guidance. This is not an isolated incident and must be dealt with urgently.

I have spoken to many doctors about cannabis. One threatened to report me to social services. One told me that cannabis costs too much. On our return from the Netherlands a doctor said that we must change Alfie's medicine to pure CBD (Epidiolex). I refused: Alfie already had an effective medicine.

I know the NHS is underfunded. But consider the needs for long term care if a child deteriorates without effective treatment. And in families with a child with epilepsy, the social impact on the full time carer (usually the mother) is immense. Consider the mental health problems, the family breakdowns because of the strain of having a disabled child. The costs to society and to the NHS far exceed those of a product that may just give all these families a life worth living.

\section{Struggle to breathe}

I am often asked why I campaigned for my son and now other families like ours in the UK. My family is everything to me. I have watched my son struggle to breathe when he is having a seizure, seen my daughter cry when I leave her, and noticed my partner anxious and worried about the future.

We became campaigners because we had no choice. We are our child's only advocates, and we must do all we can to be heard. I have watched my child develop and enjoy life, and every child with intractable epilepsy should have the right to try cannabis medicines that could save them from a life of suffering.

Competing interests: I have read and understood BMJ's policy on declaration of interests and declare that I work as a paid patient advocate specialist one day a week for European Cannabis Holdings, a medical cannabis investment group, for which Mike Barnes is clinical director. I continue to campaign unpaid for End Our Pain.

Provenance and peer review: Commissioned; not externally peer reviewed.

1 Hawkes N. Cannabis based drugs: how will they be used in practice?BMJ 2018;363:k4665. 10.1136/bmj.k4665 30560790

2 Hurley R. Medical cannabis: no NHS patients have benefited from law change, say campaigners. BMJ 2019;364:1753. 10.1136/bmj.1753 30770373

3 Hancock M. House of Commons official report (Hansard). Access to medical cannabis. 8 Apr 2019: col 26. http://bit.ly/2UGpqHn.

Published by the BMJ Publishing Group Limited. For permission to use (where not already granted under a licence) please go to http://group.bmj.com/group/rights-licensing/ permissions 